\title{
PENINGKATAN MOTIVASI BELAJAR PKN SISWA KELAS IX.7 SMP 21 KOTA PEKANBARU MELALUI PENERAPAN MODEL PEMBELAJARAN KOOPERATIF TIPE NUMBER HEADS TOGETHER
}

\author{
Elida \\ SMP Negeri 21 Pekanbaru \\ e-mail: elida121162@yahoo.com
}

\begin{abstract}
This study aims to determine the improvement of learning motivation of PKN for students class IX.7 SMP 21 Pekanbaru City through the implementation of cooperative learning model type number heads together. The study was conducted for 1 month, starting from August 2015. The study was a classroom action research. Instrument of this research consist of instrument of learning device and instrument of data collecting in the form of observation of learning motivation. Based on the results of the analysis and the previous discussion can be concluded that the application of cooperative learning method type number heads together can improve the motivation of learning PKN for students class IX.7 SMP 21 Pekanbaru City. In the first cycle, the percentage of learning motivation obtained by students is only 50.4\%, while in the second cycle it increases to $76.9 \%$. This means a percentage increase of $26.5 \%$ from cycle I to cycle II. This success is caused by the use of cooperative learning method type heads together encourage students to more actively express ideas and opinions, as well as foster a sense of responsibility in each student to help a group of friends. The learning atmosphere also makes students feel enjoy, happy and eager in learning. With these conditions will improve students' learning motivation.
\end{abstract}

Keywords-Cooperative learning method, type number heads together, learning motivation.

\begin{abstract}
Abstrak
Penelitian ini bertujuan untuk mengetahui peningkatan motivasi belajar PKN siswa kelas IX.7 SMP 21 Kota Pekanbaru melalui penerapan model pembelajaran kooperatif tipe number heads together. Penelitian dilaksanakan selama 1 bulan, mulai dari bulan Agustus 2015. Bentuk penelitian adalah penelitian tindakan kelas. Instrumen penelitian ini terdiri dari instrumen perangkat pembelajaran dan instrumen pengumpulan data berupa observasi motivasi belajar. Berdasarkan hasil analisis dan pembahasan sebelumnya dapat disimpulkan bahwa dengan penerapan metode pembelajaran kooperatif tipe number heads together dapat meningkatkan motivasi belajar PKN siswa kelas IX.7 SMP 21 Kota Pekanbaru. Pada siklus I persentase motivasi belajar yang diperoleh siswa hanya 50,4\%, sedangkan pada siklus kedua meningkat menjadi 76,9\%. Artinya terjadi peningkatan persentase sebesar $26,5 \%$ dari siklus I ke siklus II. Keberhasilan ini disebabkan dengan menggunakan metode pembelajaran kooperatif tipe number heads together mendorong siswa untuk lebih aktif mengungkapkan ide dan pendapatnya, juga menumbuhkan rasa tanggung jawab pada setiap siswa untuk membantu teman sekelompoknya. Suasana pembelajaran juga membuat siswa merasa menikmati, senang dan bersemangat dalam belajar. Dengan kondisi tersebut akan meningkatkan motivasi belajar siswa.
\end{abstract}

Kata kunci-Model pembelajaran kooperatif, tipe number heads together, motivasi belajar.

\section{PENDAHULUAN}

Sampai saat ini persoalan pendidikan yang dihadapi bangsa Indonesia adalah rendahnya mutu pendidikan pada setiap jenjang dan satuan pendidikan, khususnya pendidikan dasar dan menengah. Berbagai upaya untuk meningkatkan mutu pendidikan tersebut terus dilakukan. Upaya sentralnya berporos pada pembaruan kurikulum pendidikan. Ini terbukti dengan adanya perubahan 
dari KBK (Kurikulum Berbasis Kompetensi) menjadi KTSP (Kurikulum Tingkat Satuan Pendidikan).

Masnur Muslich (2007:20) mengemukakan bahwa KBK (Kurikulum Berbasis Kompetensi) dan KTSP (Kurikulum Tingkat Satuan Pendidikan) dikembangkan berdasarkan beberapa karakteristik atau ciri utama. Misalnya berfokus pada tiga ciri utama, yaitu (1) berpusat pada siswa, (2) memberikan mata pelajaran dan pengalaman belajar yang relevan dan kontekstual, dan (3) mengembangkan mental yang kaya dan kuat pada siswa.

Dengan ciri di atas, maka guru dituntut untuk mampu meningkatkan kualitas belajar para siswa dalam bentuk kegiatan belajar yang dapat menghasilkan pribadi yang mandiri, pelajar yang efektif, dan pekerja yang produktif. Dalam hubungan ini, guru memegang peranan yang amat penting dalam menciptakan suasana pembelajaran yang sebaik-baiknya. Guru tidak terbatas hanya sebagai pengajar dalam arti penyampai pengetahuan, akan tetapi lebih meningkat sebagai perancang pembelajaran, manejer pembelajaran, penilai hasil belajar, dan sebagai direktur belajar.

Keberhasilan belajar siswa dapat ditentukan oleh motivasi belajar yang dimilikinya. Siswa yang memiliki motivasi belajar yang tinggi cenderung prestasi belajarnya akan tinggi pula; sebaliknya siswa yang motivasi belajarnya rendah, akan rendah pula prestasi belajarnya. Sebab motivasi merupakan penggerak atau pendorong untuk melakukan tindakan tertentu. Tinggi rendahnya motivasi dapat menentukan tinggi rendahnya usaha atau semangat seseorang untuk beraktivitas, dan tentu saja tinggi rendahnya semangat akan menentukan hasil diperoleh.

Sebagaimana dikemukakan oleh Wina Sanjaya (2008:249) bahwa dalam proses pembelajaran motivasi merupakan salah satu aspek dinamis yang sangat penting. Sering terjadi siswa yang kurang berprestasi bukan disebabkan oleh kemampuannya yang kurang, akan tetapi dikarenakan tidak adanya motivasi untuk belajar sehingga ia tidak berusaha untuk mengerahkan segala kemampuannya.

Berdasarkan penjelasan tersebut jelaslah bahwa mata pelajaran pendidikan kewarganegaraan merupakan pendidikan yang bertujuan membentuk peserta didik menjadi manusia yang bertanggung jawab, cerdas sebagaimana tertuang dalam Undang-Undang No 20 tahun 2003 tentang Sisdiknas. Dari hasil pengamatan dan pengalaman di kelas IX. 7 SMP 21 Kota Pekanbaruditemui gejala khususnya pada pelajaran PKn yaitu dari 39 siswa hanya 10 orang yang tergolong aktif dalam tanya jawab dengan guru kelas. Sedangkan sisanya kurang semangatnya dalam belajar.

Dari fenomena-fenomena atau gejala di atas, terlihat bahwa pembelajaran yang dilaksanakan oleh guru khususnya pada bidang studi PKn kurang menarik perhatian siswa dan terkesan membosankan. Dengan kata lain dapat dikatakan bahwa motivasi belajar anak pada bidang studi Pkn cenderung rendah. Dari pengamatan sementara penulis, rendahnya motivasi belajar siswa dipengaruhi oleh cara mengajar guru yang kurang melibatkan siswa dalam pembelajaran. Namun anggapan ini masih harus dilakukan pengkajian yang lebih dalam. Menghadapi rendahnya motivasi belajar siswa, guru berupaya meningkatkan motivasi belajar siswa dengan penugasan maupun diskusi, tanya jawab namun belum menunjukkan hasil yang optimal, hanya siswa-siswa tertentu saja yang mau mengajukan pendapat ataupun pertanyaan pada guru ketika menerangkan pelajaran di kelas.

Slavin (2008:103) mengemukakan bahwa semua metode pembelajaran kooperatif menyumbangkan ide bahwa siswa yang bekerja sama delam belajar bertanggung jawab terhadap teman satu timnya mampu membuat diri mereka belajar sama baiknya. Salah satu model pembelajaran kooperatif yang dapat digunakan adalah pembalajaran kooperatif tipe Number Heads Together.

Berdasarkan uraian di atas penulis tertarik untuk melakukan penelitian dengan menerapkan pembelajaran kooperatif Tipe Number Heads Together dengan harapan dapat meningkatkan motivasi belajar PKn siswa kelas IX. 7 SMP 21 Kota Pekanbaru. Adapun judul penelitian ini adalah "Peningkatan Motivasi Belajar PKn Siswa Kelas IX. 7 SMP 21 Kota Pekanbaru Melalui Penerapan Model Pembelajaran Kooperatif Tipe Number Heads Together." 


\section{METODE}

Penelitian tindakan kelas ini dilaksanakan di kelas IX. 7 SMP 21 Kota Pekanbaru dengan jumlah siswa sebanyak 39 orang. Penelitian ini dilakukan pada bulan Agustus 2015 dalam beberapa siklus.

Subjek yang diteliti adalah siswa kelas IX. 7 SMP 21 Kota Pekanbaru, karakteristiknya adalah dari keseluruhan siswa memiliki semangat belajar yang bervariasi dan cenderung rendah.

Perencanaan merupakan persiapan yang dilakukan sebelum pelaksanaan tindakan. Adapun yang akan dipersiapkan yaitu:

a. Menyusun rencana pembelajaran berdasarkan langkah-langkah Pembelajaran kooperatif tipe number heads together.

b. Meminta kesediaan teman sejawat untuk menjadi observer dalam pelaksanaan pembelajaran.

c. Menyiapkan format pengamatan atau lembar observasi terhadap aktivitas yang dilakukan guru dan aktivitas yang dilakukan siswa dan lembar observasi motivasi belajar siswa.

Penelitian ini terdiri dari beberapa siklus. Adapun setiap siklus dilakukan dalam 3 kali pertemuan. Tiap siklus terdiri dari langkah-langkah perencanaan/persiapan tindakan, pelaksanaan tindakan, observasi dan refleksi. Setelah hasil pada siklus I diperoleh dan telah direfleksi selanjutnya dilakukan perbaikan untuk melanjutkan ke siklus berikutnya.

\section{HASIL DAN PEMBAHASAN}

\section{Hasil Penelitian}

\section{Siklus Pertama}

Berdasarkan hasil pengamatan observer aktivitas guru dalam pembelajaran dengan menggunakan pembelajaran kooperatif tipe number heads together dapat dilihat pada tabel IV.1 berikut ini.

Tabel IV. 1. Aktivitas Guru pada Siklus

\begin{tabular}{|c|c|c|c|}
\hline No & $\begin{array}{c}\text { Pelaksanaan } \\
\text { Aktivitas }\end{array}$ & Jumlah & Skor \\
\hline 1 & $\begin{array}{l}\text { Sangat } \\
\text { sempurna }\end{array}$ & $\begin{array}{lll}0 & \mathrm{x} & 5\end{array}$ & 0 \\
\hline 2 & Sempurna & $2 \times 4$ & 8 \\
\hline 3 & $\begin{array}{l}\text { Kurang } \\
\text { sempurna }\end{array}$ & $\begin{array}{lll}4 & \mathrm{x} & 3\end{array}$ & 12 \\
\hline 4 & $\begin{array}{l}\text { Tidak } \\
\text { sempurna }\end{array}$ & $\begin{array}{lll}0 & \mathrm{x} & 2 \\
\end{array}$ & 0 \\
\hline 5 & $\begin{array}{l}\text { Tidak } \\
\text { dilaksanakan }\end{array}$ & $\begin{array}{lll}0 & \mathrm{x} & 1\end{array}$ & 0 \\
\hline Jumlah & & \multicolumn{2}{|l|}{20} \\
\hline Klasifikasi & & \multicolumn{2}{|c|}{$\begin{array}{c}\text { Cukup } \\
\text { sempurna }\end{array}$} \\
\hline
\end{tabular}

Sumber: Data hasil observasi, 2015

Dari tabel di atas diketahui skor yang diperoleh guru dalam pelaksanaan pembelajaran dengan penggunaan pembelajaran kooperatif tipe number heads together setelah dibandingkan dengan standar klasifikasi yang telah ditetapkan di Bab III. Aktifitas guru pada siklus I mendapat skor 20 yang berada pada interval 16 - 20 dengan kategori cukup sempurna

Kelemahan-kelemahan yang dilakukan guru yang telah dipaparkan sebelumnya mempengaruhi aktivitas siswa. Adapun mengenai aktivitas siswa dalam proses pembelajaran 
dengan penggunaan pembelajaran kooperatif tipe number heads together dapat dilihat pada tabel berikut

Tabel IV. 2. Aktivitas Belajar Siswa Pada Mata pelajaran PKn

\begin{tabular}{|c|c|c|c|}
\hline No & Aktivitas siswa & Skor & $\%$ \\
\hline 1 & $\begin{array}{l}\text { Siswa medengarkan penjelasan guru berkaitan dengan materi } \\
\text { yang diajarkan. }\end{array}$ & 24 & 61.5 \\
\hline 2 & Siswa menyelesaikan soal berkaitan dengan materi & 16 & 41.0 \\
\hline 3 & $\begin{array}{l}\text { Siswa membentuk kelompok dengan cepat dan memperoleh } \\
\text { nomor. }\end{array}$ & 15 & 38.5 \\
\hline 4 & Siswa bekerjasama dalam mengerjakan tugas kolompok. & 18 & 46.2 \\
\hline 5 & $\begin{array}{l}\text { Siswa dalam kelompok memutuskan jawaban yang dianggap } \\
\text { paling benar dan memastikan setiap kelompok mengetahui } \\
\text { jawaban ini. }\end{array}$ & 17 & 43.6 \\
\hline 6 & $\begin{array}{l}\text { Siswa dengan nomor yang dipanggil melaporkan hasil kerja } \\
\text { mereka }\end{array}$ & 18 & 46.2 \\
\hline \multicolumn{2}{|c|}{ Jumlah } & 108 & \\
\hline \multicolumn{2}{|c|}{ Rata-rata } & & 46.2 \\
\hline \multicolumn{2}{|c|}{ Klasifikasi } & Rendah & \\
\hline
\end{tabular}

Sumber: Data Hasil Observasi, 2015

Berdasarkan tabel IV.2 maka diketahui skor aktivitas siswa secara umum berklasifikasi "rendah" dengan rata-rata 50.0\%, skor aktivitas siswa 108 berada pada inteval 55 - 108 dengan kategori rendah. Walaupun sebagian besar siswa telah menunjukkan keinginannya untuk belajar namun masih terdapat siswa yang kurang perhatian dalam belajarnya. Khususnya pada aktivitas, (3) Siswa membentuk kelompok dengan cepat dan memperoleh nomor (2) Siswa menyelesaikan soal berkaitan dengan materi, (5) Siswa dalam kelompok memutuskan jawaban yang dianggap paling benar dan memastikan setiap kelompok mengetahui jawaban ini, dan (6) Siswa dengan nomor yang dipanggil melaporkan hasil kerja mereka.

Berdasarkan hasil pengamatan terhadap tingkat motivasi belajar siswa, pada siklus I terlihat bahwa motivasi belajar siswa masih tergolong rendah dengan skor 108. untuk lebih jelasnya dapat dilihat pada tabel berikut ini:

Tabel IV. 3. Motivasi Belajar Siswa pada Siklus I

\begin{tabular}{|c|l|c|c|}
\hline No & \multicolumn{1}{|c|}{ Aktivitas siswa } & Skor & $\%$ \\
\hline 1 & Adanya peningkatan aktivitas belajar & 24 & 61.5 \\
\hline 2 & Adanya peningkatan upaya belajar & 15 & 38.5 \\
\hline 3 & Kegembiraan dalam belajar & 26 & 66.7 \\
\hline 4 & Tidak mudah mengeluh & 24 & 61.5 \\
\hline 5 & Tidak pernah putus asa & 15 & 38.5 \\
\hline 6 & Keinginan belajar dengan serius & 14 & 35.9 \\
\hline Jumlah & $\mathbf{1 1 8}$ \\
\hline Rata-rata & \multicolumn{2}{|c|}{$\mathbf{5 0 . 4}$} \\
\hline Klasifikasi & \multicolumn{2}{c}{ Rendah } \\
\hline
\end{tabular}

Sumber: Data hasil observasi, 2015

Berdasarkan hasil pengamatan terhadap tingkat motivasi belajar siswa dan berpedoman pada kriteria yang ditetapkan, pada siklus I menunjukkan bahwa motivasi belajar siswa masih tergolong rendah dengan skor 118. Rendahnya motivasi belajar siswa terlihat pada aspek motivasi belajar yaitu adanya peningkatan upaya belajar, tak pernah putus asa, dan keinginan belajar dengan serius hanya $50.4 \%$. 


\section{Siklus Kedua}

Berdasarkan hasil pengamatan observer aktivitas guru dalam pembelajaran dengan menggunakan pembelajaran kooperatif tipe number heads together dapat dilihat pada tabel IV.4 berikut ini.

Tabel IV. 4. Aktivitas Guru pada Siklus II

\begin{tabular}{|c|l|c|c|c|c|c|}
\hline NO & \multicolumn{1}{|c|}{ AKTIFITAS YANG DIAMATI } & \multicolumn{2}{|c|}{ Dilaksanakan } & \multicolumn{2}{|c|}{$\begin{array}{c}\text { Tidak } \\
\text { Dilaksanakan }\end{array}$} \\
\cline { 4 - 6 } & & \multicolumn{1}{|c|}{ SS } & S & CS & KS & \\
\hline 2 & Guru menjelaskan materi yang akan dipelajari & 5 & & & & \\
\hline 2 & $\begin{array}{l}\text { Guru memberi kesempatan kepada beberapa siswa untuk menyelesaikan soal berkaitan } \\
\text { dengan materi }\end{array}$ & 4 & & & \\
\hline 3 & Siswa dibagi menjadi beberapa kolompok. Setiap siswa dan kelompok mendapatkan nomor. & 4 & & & \\
\hline 4 & Guru memberikan tugas dan masing-masing kolompok mengerjakannya. & & 4 & & & \\
\hline 5 & $\begin{array}{l}\text { Guru meminta kelompok memutuskan jawaban yang dianggap paling benar dan memastikan } \\
\text { setiap kelompok mengetahui jawaban ini. }\end{array}$ & 4 & & & \\
\hline 6 & $\begin{array}{l}\text { guru memanggil salah satu nomor. Siswa dengan nomor yang dipanggil melaporkan hasil } \\
\text { kerja mereka. }\end{array}$ & 5 & & & \\
\hline & Skor aktivitas guru & $\mathbf{1 0}$ & $\mathbf{1 6}$ & $\mathbf{0}$ & $\mathbf{0}$ & $\mathbf{0}$ \\
\hline JUMLAH & & $\mathbf{2 6}$ \\
\hline
\end{tabular}

Sumber: Data Hasil Observasi, 2015

Dari tabel di atas diketahui skor yang diperoleh guru dalam pelaksanaan pembelajaran dengan penggunaan pembelajaran kooperatif tipe number heads together pada Siklus II setelah dibandingkan dengan standar klasifikasi yang telah ditetapkan di Bab III. Aktifitas guru pada siklus II ini mencapai skor 26 yang berada pada interval 26 - 30 dengan kategori sangat sempurna. Aktivitas guru telah dilakukan dengan sangat sempurna adalah Guru menjelaskan materi yang akan dipelajari dan Guru memanggil salah satu nomor. Siswa dengan nomor yang dipanggil melaporkan hasil kerja mereka. Adapun aspek lainnya dilakukan guru dengan penilaian sempurna .

Adanya peningkatan aktivitas guru dalam proses pembelajaran memberikan pengaruh posistif pada aktivitas siswa. Berdasarkan pengamatan observer berkaitan dengan aktivitas siswa pada siklus II melalui hasil observasi "aktivitas siswa" yang diukur dari 6 komponen, aktivitas siswa memperoleh skor 181 dengan kriteria sangat tinggi. Untuk lebih jelasnya dapat dilihat pada Tabel berikut ini:

Tabel IV. 5. Aktivitas Belajar Siswa pada Siklus II

\begin{tabular}{|c|l|c|c|}
\hline No & \multicolumn{1}{|c|}{ Aktivitas siswa } & Skor & $\%$ \\
\hline 1 & Siswa medengarkan penjelasan guru berkaitan dengan materi yang diajarkan. & 30 & 76.9 \\
\hline 2 & Siswa menyelesaikan soal berkaitan dengan materi & 32 & 82.1 \\
\hline 3 & Siswa membentuk kelompok dengan cepat dan memperoleh nomor. & 29 & 74.4 \\
\hline 4 & Siswa bekerjasama dalam mengerjakan tugas kolompok. & 30 & 76.9 \\
\hline 5 & memastikan setiap kelompok mengetahui jawaban ini. & 32 & 82.1 \\
\hline 6 & Siswa dengan nomor yang dipanggil melaporkan hasil kerja mereka & 28 & 71.8 \\
\hline Jumlah & $\mathbf{1 8 1}$ \\
\hline Rata-rata & \multicolumn{3}{|c|}{$\mathbf{7 7 . 4}$} \\
\hline Klasifikasi & \multicolumn{2}{|c|}{ Sangat tinggi } \\
\hline
\end{tabular}

Sumber: Data Hasil Observasi, 2015

Berdasarkan tabel IV.5 maka diketahui skor aktivitas siswa mencapai 181 yang berada pada inteval 163 - 216 dengan kategori sangat tinggi. Rata-rata aktivitas siswa adalah 77.4\%.

Adapun mengenai aktivitas guru dalam menggunakan metode pembelajaran kooperatif tipe number head together, jika pada siklus I guru sudah melakukan dengan "cukup sempurna". Hasil pengamatan aktivitas guru pada siklus II menunjukkan adanya peningkatan dengan skor 26 dengan kriteria sangat sempurna.

Dari hasil observasi motivasi belajar pada siklus II diketahui bahwa motivasi belajar siswa mencapai skor 180 dengan kriteria sangat tinggi, rata-rata persentase indikator motivasi belajar siswa sebesar 76.9\%. lebih jelasnya dapat dilihat pada tabel berikut ini: 
Tabel IV. 6. Motivasi Belajar Siswa pada Siklus II

\begin{tabular}{|c|c|c|c|}
\hline No & Aktivitas siswa & Skor & $\%$ \\
\hline 1 & $\begin{array}{l}\text { Adanya peningkatan aktivitas } \\
\text { belajar }\end{array}$ & 31 & 79.5 \\
\hline 2 & $\begin{array}{l}\text { Adanya peningkatan upaya } \\
\text { belajar }\end{array}$ & 28 & 71.8 \\
\hline 3 & Kegembiraan dalam belajar & 32 & 82.1 \\
\hline 4 & Tidak mudah mengeluh & 31 & 79.5 \\
\hline 5 & Tidak pernah putus asa & 29 & 74.4 \\
\hline 6 & Keinginan belajar dengan serius & 29 & 74.4 \\
\hline \multicolumn{2}{|r|}{ Jumlah } & 180 & \\
\hline \multicolumn{2}{|c|}{ Rata-rata } & \multirow{2}{*}{\multicolumn{2}{|c|}{$\begin{array}{l}76.9 \\
\text { Sangat tinggi }\end{array}$}} \\
\hline \multicolumn{2}{|c|}{ Klasifikasi } & & \\
\hline
\end{tabular}

Sumber: Data Hasil Observasi, 2015

Berdasarkan data di atas diketahui bahwa tingkat motivasi siswa pada siklus II berada pada klasifikasi sangat tinggi karena skor 180 berada pada interval skor 163 - 216 dengan rata-rata persentase indikator motivasi belajar siswa sebesar $76.9 \%$

Dari hasil observasi motivasi belajar siswa pada Siklus I hanya mencapai skor 118 yaitu dalam kriteria rendah, dengan rata-rata motivasi belajar siswa untuk tiap indikator (6 indikator) motivasi belajar hanya sebesar $50.4 \%$. Sedangkan hasil pengamatan motivasi belajar pada siklus II terjadi peningkatan mencapai 58 poin atau peningkatan rata-rata indikator motivasi belajar siswa (6 indikator) sebesar $26.5 \%$.

Dilihat distribusi atau penyebarannya dari masing-masing indikator, menunjukkan dari masih ada indikator yang belum mencapi kriteria keberhasilan penerapan pembelajaran kooperatif tipe number heads together di bawah $75 \%$ yaitu pada indikator (2) Adanya peningkatan upaya belajar, (5) tidak pernah putus asa dan (6) Keinginan belajar dengan serius, namun secara garis besar, motivasi belajar siswa telah mencapai tolak ukur yang dipergunakan yaitu rata-rata di atas $75 \%$.

\section{Pembahasan}

Dari hasil observasi terhadap 6 indikator motivasi belajar siswa pada siklus pertama menunjukkan bahwa motivasi belajar siswa masih tergolong rendah dengan skor 118, dengan ratarata persentase motivasi belajar sebesar 50.4\%. Sedangkan pada siklus II mencapai skor 180 dengan kriteria sangat tinggi dan persentase rata-rata motivasi belajar siswa sebesar $76.9 \%$. Hal ini disebabkan pengelolaan pembelajaran pada siklus I yang belum optimal pada beberapa aspek seperti dijelaskan dalam siklus I dan telah diperbaiki pada siklus II ini.

Kelemahan-kelemahan penerapan pada siklus I tersebut setelah diperbaiki pada siklus II ternyata dapat meningkatkan motivasi belajar siswa. Melalui perbaikan proses pelaksanaan metode pembelajaran kooperatif tipe number heads together pada siklus II tersebut, motivasi belajar siklus II mencapai skor 180 dengan kriteria sangat tinggi, persentase rata-rata 6 indikator motivasi belajar sebesar 76.9\%.

Berkaitan dengan hasil pengamatan terhadap aktivitas siswa lebih jauh dapat dijelaskan bahwa siswa telah mendapat kesempatan untuk membagikan ide dan mempertimbangkan jawaban yang paling tepat. Selain itu, teknik ini juga mendorong siswa untuk meningkatkan semangat kerja sama mereka, walaupun belum terjadi pada seluruh siswa. Hal ini disebabkan karena siswa belum terbiasa dengan pembelajaran yang diterapkan oleh peneliti. Suasana pembelajaran masih terasa kaku dan kurang berkembang, sehingga siswa kurang memiliki kebebasan dalam bekerjasama. 
Perbandingan antara motivasi belajar pada Siklus I dan Siklus II secara jelas dapat dilihat pada Tabel berikut ini:

Tabel IV. 7. Rekapitulasi Motivasi Belajar Siswa pada Siklus I dan Siklus II

\begin{tabular}{|c|c|c|c|c|c|c|c|c|c|}
\hline \multicolumn{2}{|r|}{ SIKLUS } & \multicolumn{6}{|c|}{ MOTIVASI SISWA } & \multirow[t]{2}{*}{ Jumlah } & \multirow{2}{*}{$\begin{array}{l}\text { Rata- } \\
\text { rata }\end{array}$} \\
\hline & & 1 & 2 & 3 & 4 & 5 & 6 & & \\
\hline \multirow[t]{2}{*}{ I } & Jumlah siswa & 24 & 15 & 26 & 24 & 15 & 14 & \multirow[t]{2}{*}{118} & \multirow[b]{2}{*}{50.4} \\
\hline & Persentase (\%) & 61.5 & 38.5 & 66.7 & 61.5 & 38.5 & 35.9 & & \\
\hline \multirow[t]{2}{*}{ II } & Jumlah siswa & 31 & 28 & 32 & 31 & 29 & 29 & \multirow[t]{2}{*}{180} & \multirow[b]{2}{*}{76.9} \\
\hline & Persentase (\%) & 79.5 & 71.8 & 82.1 & 79.5 & 74.4 & 74.4 & & \\
\hline
\end{tabular}

Sumber: Data Hasil Observasi, 2015

Perbandingan antara motivasi belajar antara siklus I dan siklus II, juga ditampilkan dalam bentuk diagram batang berikut ini:

Gambar 1. Histogram Motivasi Belajar Siklus I dan II

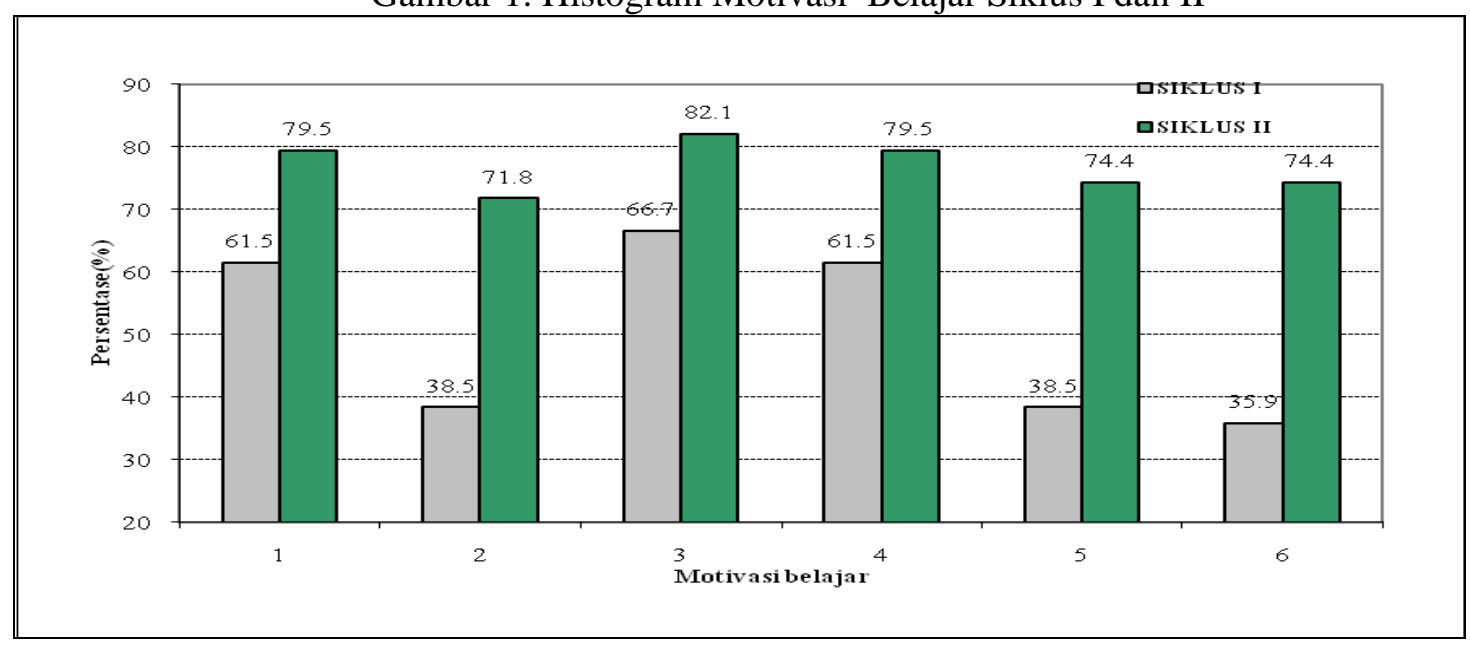

Keterangan motivasi siswa:

1. Adanya peningkatan aktivitas belajar

2. Adanya peningkatan upaya belajar

3. Kegembiraan dalam belajar

4. Tidak mudah mengeluh

5. Tidak pernah putus asa

6. Keinginan belajar dengan serius

Berdasarkan Tabel IV.7. dan histogram di atas diketahui bahwa terjadinya peningkatan motivasi belajar siswa dari siklus I ke siklus II. Secara rinci diketahui bahwa pada indikator (1) Adanya peningkatan aktivitas belajar mengalami peningkatan dari $61.5 \%$ menjadi $79.5 \%$. Pada indikator (2) Adanya peningkatan upaya belajar mengalami peningkatan dari $38.5 \%$ menjadi $71.8 \%$. Pada indikator (3) Kegembiraan dalam belajar pada siklus I mengalami peningkatan dari $66.7 \%$ menjadi $82.1 \%$. Pada indikator (4) Tidak mudah mengeluh mengalami peningkatan dari $61.5 \%$ menjadi $79.5 \%$. Pada indikator (5) Tidak pernah putus asa mengalami peningkatan dari $38.5 \%$ menjadi $74.4 \%$. Pada indikator terakhir (6) Keinginan belajar dengan serius mengalami peningkatan dari $35.9 \%$ menjadi $74.4 \%$.

Meskipun pada penerapan metode pembelajaran kooperatif tipe number heads together masih ada indikator yang belum mencapi kriteria keberhasilan atau di bawah 75\%, namun secara garis besar, motivasi belajar siswa telah berhasil mencapai tolak ukur yang dipergunakan yaitu rata-rata di atas $75 \%$.

Meningkatnya motivasi belajar siswa pada siklus II dibandingkan pada siklus I menunjukkan bahwa perbaikan pembelajaran yang dibawakan dapat memecahkan permasalahan yang dihadapi. Artinya, perencanaan pembelajaran yang dibuat sesuai untuk mengatasi 
permasalahan rendahnya motivasi belajar siswa yang terjadi di dalam kelas selama ini. Selanjutnya, adanya peningkatan motivasi belajar siswa pada mata pelajaran PKn dari sebelumnya ke siklus I dan kesiklus II menunjukkan bahwa penerapan metode pembelajaran kooperatif tipe number heads together dapat meningkatkan motivasi belajar PKn siswa kelas IX. 7 SMP 21 Kota Pekanbaru.

Sebagaimana telah dipaparkan sebelumnya bahwa menurut Slavin (dalam Sanjaya, 2007:240) mengemukakan pembelajaran kooperatif dapat meningkatkan prestasi belajar siswa sekaligus dapat meningkatkan kemampuan hubungan sosial, menumbuhkan sikap menerima kekurangan diri dan orang lain, serta dapat meningkatkan harga diri. Pembelajaran kooperatif dapat merealisasikan kebutuhan siswa dalam berfikir, memecahkan masalah, dan mengintegrasikan pengetahuan dengan keterampilan. Melalui kerjasama antar siswa yang heterogen dapat meningkatkan motivasi belajar siswa.

Lie (2007:59) menyatakan bahwa model pembelajaran kooperatif teknik Number Head Together memberikan kesempatan kepada siswa untuk membagikan ide dan mempertimbangkan jawaban yang paling tepat. Selain itu, teknik ini juga mendorong siswa untuk meningkatkan semangat kerja sama mereka. Selain itu, teknik ini juga mendorong siswa meningkatkan semangat kerjasama mereka

Dari pemaparan teori tentang pembelajaran kooperatif model Number Heads Together dapat diketahui bahwa metode ini mendorong siswa untuk lebih aktif mengungkapkan ide dan pendapatnya. Serta dituntut menguasai materi yang sedang dibahas. Penerapan pembelajaran ini juga akan meningkatkan keaktifan siswa dan menumbuhkan rasa tanggung jawab pada setiap siswa untuk membantu teman sekelompoknya. Dengan demikian maka motivasi belajar siswa akan meningkat dan mendukung tercapainya tujuan belajar siswa.

\section{Hipotesis}

Dari hasil penelitian dan pembahasan seperti telah diuraikan di atas menjelaskan bahwa penerapan metode pembelajaran kooperatif tipe number heads together secara benar maka aktivitas siswa menjadi lebih aktif dan pada gilirannya motivasi belajar siswa menjadi lebih baik. Adanya peningkatan aktivitas guru dalam menerapkan metode pembelajaran kooperatif tipe number heads together dari siklus I ke Siklus II seiring dengan peningkatan motivasi belajar siswa dari siklus I ke Siklus II.

Informasi ini membuktikan bahwa hipotesis peneliti yang berbunyi "Dengan penerapan metode pembelajaran kooperatif tipe number heads together dapat meningkatkan motivasi belajar PKn siswa kelas IX. 7 SMP 21 Kota Pekanbaru "diterima".

\section{KESIMPULAN}

\section{Kesimpulan}

Berdasarkan hasil analisis dan pembahasan sebelumnya dapat disimpulkan bahwa dengan penerapan metode Pembelajaran Kooperatif tipe number heads together dapat meningkatkan Motivasi Belajar PKn siswa kelas IX. 7 SMP 21 Kota Pekanbaru. Dimana pada siklus I persentase motivasi belajar yang diperoleh siswa hanya 50,4\%, sedangkan pada siklus kedua meningkat menjadi $76,9 \%$. Artinya terjadi peningkatan persentase sebesar $26,5 \%$ dari siklus I ke siklus II. Keberhasilan ini disebabkan dengan menggunakan metode pembelajaran kooperatif tipe number heads together mendorong siswa untuk lebih aktif mengungkapkan ide dan pendapatnya, juga menumbuhkan rasa tanggung jawab pada setiap siswa untuk membantu teman sekelompoknya. Suasana pembelajaran juga membuat siswa merasa menikmati, senang dan bersemangat dalam belajar. Dengan kondisi tersebut akan meningkatkan motivasi belajar siswa.

\section{Tindakan yang Dilakukan}

Adapun hasil penelitian menunjukkan adanya peningkatan motivasi belajar PKn, dengan langkah-langkah yang dilakukan sebagai berikut:

1. Memberikan motivasi kepada siswa sehingga siswa mampu bekerja sama dengan baik dalam kelompoknya untuk menyelesaikan tugas kelompoknya. 
2. Guru memberikan batas waktu ketika siswa menyelesaikan tugas yang diberikan.

3. Guru melakukan bimbingan yang merata terhadap kelompok-kelompok siswa, dan tidak terfokus pada kelompok tertentu saja.

4. Melakukan bimbingan terhadap siswa yang kurang termotivasi dalam mengikuti proses pembelajaran.

5. Memberikan kebebasan kepada siswa untuk memilih nomor untuk dirinya sendiri.

6. Memberi kesempatan kepada siswa untuk mengeluarkan pendapat dalam kelompoknya.

\section{SARAN}

Berdasarkan pembahasan dan kesimpulan hasil penelitian dari penerapan metode pembelajaran kooperatif tipe Number Heads Together yang dapat meningkatkan motivasi Belajar PKn siswa kelas IX. 7 SMP 21 Kota Pekanbaru, peneliti mengajukan beberapa saran, yaitu:

1) Sebaiknya pelaksanaan metode pembelajaran kooperatif tipe Number Heads Together lebih sering diterapkan untuk meningkatkan motivasi belajar siswa dan dalam materi atau pokok bahasan yang sesuai.

2) Dalam penerapan metode pembelajaran kooperatif tipe Number Heads Together, sebaiknya guru lebih memberi kesempatan anggota kelompok untuk memperluas wawasan dan memperkaya diri dalam berfikir, bernegosiasi, berargumentasi dan berkembang.

3) Guru lebih dapat mengarahkan kegiatan belajar yang berpusat pada siswa, selalu membesarkan semangat belajar siswa, dan menghargai upaya atau hasil usaha belajar individu maupun kelompok.

\section{DAFTAR PUSTAKA}

[1] Angkowo. 2007. Optimalisasi Media Pembelajaran. Jakarta. Gramedia.

[2] Dimyati dan Mudjiono. 2002. Belajar dan Pembelajaran. Jakarta: Rineka Cipta.

[3] Elida Prayitno. 1989. Motivasi dalam belajar. Jakarta: P2LPTK.

[4] Etin Solihatin 2007. Cooperatif Learning Analisis Pembelajaran IPS. Jakarta. Bumi Aksara.

[5] Gimin, Dkk. 2008. Instrumen dan Pelaporan Hasil Penelitian Tindakan Kelas. Pekanbaru. Makalah Pelatihan.

[6] Prasetya, E., 2006, Case Based Reasoning untuk mengidentifikasi kerusakan bangunan, Tesis, Program Pasca Sarjana Ilmu Komputer, Univ. Gadjah Mada, Yogyakarta.

[7] Hamalik Oemar. 2004. Proses Belajar Mengajar. Jakarta: Bumi Aksara.

[8] Ibrahim, Dkk. 2000. Pembelajaran Kooperatif. Unesa University Press. Surabaya.

[9] Kunandar. 2007. Guru Profesional Implementasi Kurikulum Tingkat Satuan Pendidikan (KTSP) Dan Persiapan Menghadapi Sertifikasi Guru. Jakarta: PT. Raja Grafindo Persada.

[10] Lie Anita. 2002. Cooperative Learning, Jakarta: Grasindo.

[11] Muslich Masnur. 2007. KTSP Pembelajaran Berbasis Kompetensi dan Kontekstual Panduan Bagi Guru Kepala Sekolah dan Pengawas Sekolah. Jakarta: Bumi aksara.

[12] Sanjaya Wina. 2007. Strategi Pembelajaran Berorientasi Standar Proses Pendidikan. Jakarta: Kencana.

[13] Sardiman. 2004. Interaksi dan Motivasi Belajar Mengajar. Jakarta: Rajawali Pers.

[14] Slavin Robert E. 2008. Cooperative learning Theori Reseach and Practice. Boston: Allyn and Bacod. 